\title{
LONG WAVES OR VANISHING POINTS? A COGNITIVE APPROACH TO THE LITERARY CONSTRUCTION OF HISTORY
}

\author{
PETER HANENBERG
}

In the present paper I will try to present four theses. The first thesis discusses two monumental works as turning points of Germany's post-war literature. The second thesis - intertwined with the first - tries to show which cognitive concept of forcedynamics in history characterizes each of the works, i.e. which relation of forces the texts indicate as 'causing, 'letting', 'hindering' or 'helping' action and change. We will briefly analyse the first paragraph of each of them to identify the sense in which (third thesis) the texts establish their own limits and settings right from the beginning, creating a tacit condition inherent to the framework within which the further development of the text can take place. Finally (fourth thesis) we will explain in which sense our findings might elucidate the fact that the novels lost their status as turning points after 1989. We might ask, what is wrong in the concept of force-dynamics that characterizes each of the two works and that seems inadequate to the needs and interests of readers post-1989.

Of course there are two more theses behind my presentation that I should mention though I am not going to develop them. The first is that we can apply theories of cognitive semiotics to understand how novels and literature in general work and how they organize their force-dynamics structure in which turning points and processes (in a narrative sense) are supposed to make sense. The second is that such analyses might not just say something about literature but that this saying might be relevant for describing cultural and social changes or turning points (in the sense of History). These two theses, however, merely build the tacit ground of my presentation. I only mention them to give the reader an insight into my own limitations (Hanenberg 2011a; 2011b).

I argue that two monumental works can be considered as turning points in post-war German literature, two outstanding monuments to the attempt to understand the present through a deep reflection on the past (as Ralf Schnell pointed out in his History of Literature in the Federal Republic of Germany, 1986: 341). ${ }^{1}$ I am talking about Uwe Johnson's Jahrestage and Peter Weiss' Die Ästhetik des Widerstands.

Uwe Johnson's Jahrestage (Anniversaries. From the Life of Gesine Cresspahl) was published in four volumes; the first appeared in 1970, the second in 1971, the third in 1973 and the last one in 1983 (Johnson 1988). In 2000 Margarethe von Trotta produced an impressive film version of the book that I shall not consider here. The

\footnotetext{
${ }^{1}$ The comparison between Weiss and Johnson has been further developed by Hofmann
} 1995a, Hofmann1995b, Honold 2002, Knoche 2002, Pflugmacher 2007 and Rector 2005. 
English translation I will use for quotation is based on a cut version prepared by Johnson himself and published before the last volume actually appeared (Johnson 1975). The book is a complex text, constructed like a diary, written between August $21^{\text {st }}$ in 1967 and August $20^{\text {th }}$ in 1968 . But the story covers much more than just one year. It tells about the life of Gesine Cresspahl, her family and friends, ranging from the fictive city of Jerichow in Mecklenburg, East Germany, where she lived during the time of the Nazi-Regime, to the moment when she left the German Democratic Republic and settled, firstly, in the Federal Republic and then (after 1961) in the United States. The book ends on the day when Gesine is flying for business to Prague, still unaware that Soviet tanks have occupied the city and put down the so called Prague Spring. Gesine's reflections, her memories, the fictive dialogs with other characters like her father, her daughter, New York citizens or even the author himself ("Who's telling this story, Gesine?" the text once asks. "We both are. Surely that's obvious, Johnson." is the answer; Johnson 1975: 169). ${ }^{2}$ And together with those voices we hear others originating from historical documents or articles in the New York Times. It is not possible to summarize even one of the endless strands of these nearly 2000 pages, but it is clear the extent to which these Anniversaries are a literary representation of the 20th century's challenges, conflicts and catastrophes: from war, Nazism, and anti-Semitism to the East-West-conflict, racism and the Vietnam War. When the four volumes were finally finished, Germany seemed to have found a singular literary work representing the challenges, conflicts and catastrophes that characterized contemporary culture. Thus, Jahrestage was celebrated as an outstanding turning point in the understanding of the course of history through literature. Johnson was considered to be an exceptional writer who managed to intertwine eastern and western perspectives and stories.

Let us now take a closer look at the beginning of the text, where the main concept of history, which is to be developed throughout the novel, is initially presented.

Long waves sweep slanting against the beach, hump muscled backs, raise trembling combs that tip over at the greenest summit. The taut roll, already streaked with white, enfolds a hollow space of air that is crushed by the clear mass as if a secret had been created and destroyed there. The bursting wave knocks children off their feet, whirls them around, drags them flat over the gravelly bottom. Beyond the surf the waves tug at the swimmer, pulling her on outstretched hands over their backs. The wind is only a flutter, with a wind as slack as this the Baltic had petered out in a ripple. The word for the short waves of the Baltic was choppity. (Johnson 1975: 3) ${ }^{3}$

2 "Wer erzählt hier eigentlich, Gesine. Wir beide. Das hörst du doch, Johnson." (Johnson 1988: 256)

3 “Lange Wellen treiben schräg gegen den Strand, wölben Buckel mit Muskelsträngen, heben zitternde Kämme, die im grünsten Stand kippen. Der straffe Überschlag, schon weißlich gestriemt, umwickelt einen runden Hohlraum Luft, der von der klaren Masse zerdrückt wird, als sei da ein Geheimnis gemacht und zerstört worden. Die zerplatzende Woge stößt Kinder von den Füßen, wirbelt sie rundum, zerrt sie flach über den graupligen Grund. Jenseits der Brandung ziehen die Wellen die Schwimmende an ausgestreckten Händen 
The very first sentence of the text introduces movement: "Long waves sweep slanting against the beach", a movement that seems to occur as such, presenting an agonist in action. Let me translate my statements into the figures suggested by Leonard Talmy as instruments to identify and describe force-dynamic patterns in language and cognition (Talmy 2003: 409-470). As Talmy explains, "force dynamics figures significantly in language structure":

It is, first of all, a generalization over the traditional linguistic notion of "causative": it analyzes 'causing' into finer primitives and sets it naturally within a framework that also includes 'letting', 'hindering', 'helping', and still further notions not normally considered in the same context. (Talmy 2003: 409)

Following Talmy we call the focal force entity the "Agonist" (indiacted by a circle) and the force element that opposes it the "Antagonist" (indicated by a concave figure). We distinguish between two intrinsic force tendencies; "toward action" (arrowhead) and "toward rest" (dot). A stronger entity is marked by "+", a weaker entity by "-". Opposing force entities yield a resultant, indicated by a line beneath the Agonist, which might tend to action (arrowhead) or rest (dot) (Talmy 2003: 413-414).

Here we have our agonist (the long wave) in action:

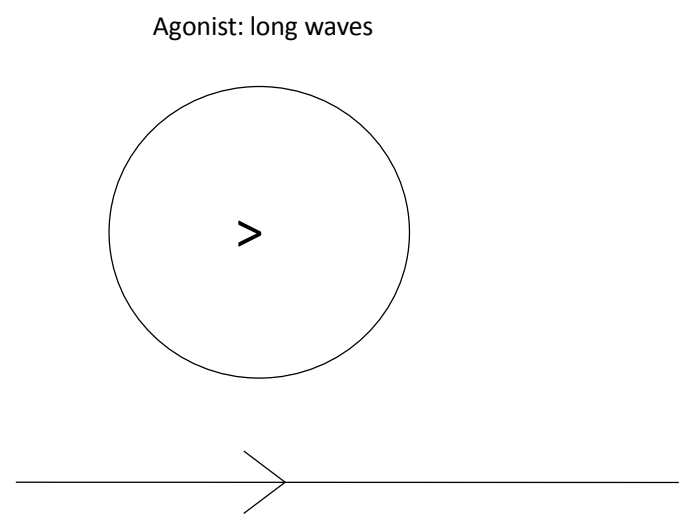

a) "Long waves sweep slanting against the beach"

Figure 1

The following lines of Johnson's text describe the inner logic of this action as a complex process of force-dynamics. The waves go ahead by "raising" and "tipping over", a top-down movement included in the forward action. This same movement is

über ihren Rücken. Der Wind ist flatterig, bei solchem drucklosen Wind ist die Ostsee in ein Plätschern ausgelaufen. Das Wort für die kurzen Wellen der Ostsee ist kabbelig gewesen." (Johnson 1988: 7) 
simultaneously presented as a creation of space ("a hollow space") which is crushed again by the same movement. The simple cadence of the waves includes, therefore, a three-dimensional opening and destruction of space, untenable in time. A comparison blends this untenable space with the concept of secret - an aspect that we cannot deal with at this moment. Only after creating and presenting the inner complexity of the waves as space and movement in time do we finally see the force-dynamic effect of it: "The bursting wave knocks children off their feet."

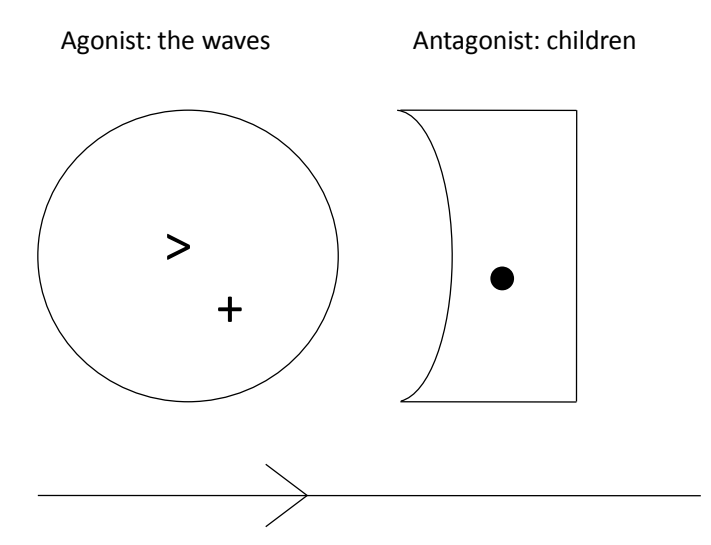

b) The bursting wave knocks children off their feet.

Figure 2

Again, this knocking over is not just a simple action, it is complex in the way that it "whirls them around, drags them flat over the gravelly bottom". These actions are elaborations of the previous schema.

But there is still another action caused by the waves "beyond the surf", when they simply pull the swimmer over their backs, not causing any destruction or confusion. Outstretched hands guarantee the swimmer's stability: 


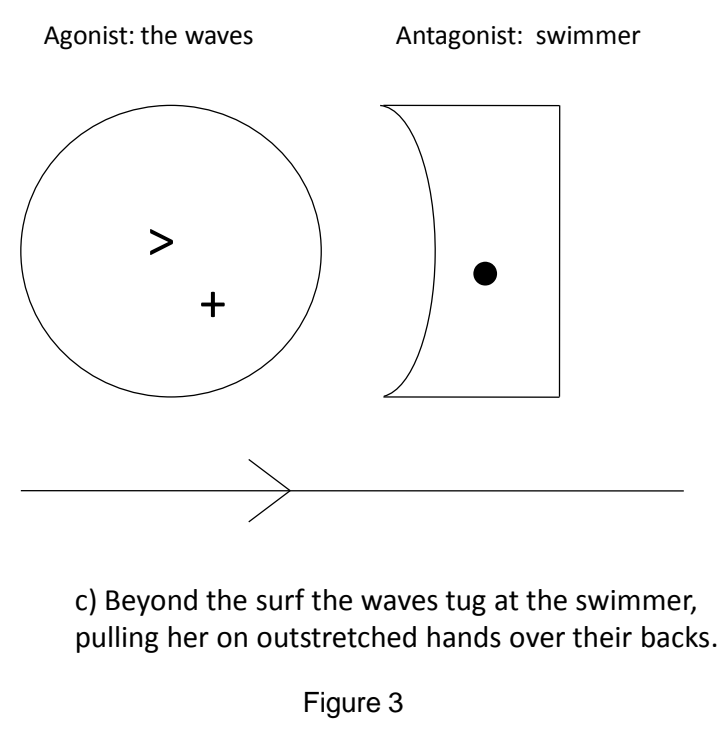

The outcome of the waves' activity is not certain: it can "knock [someone] off" his feet or simply "pull [him] over", which seems to be a question of position.

Finally the text introduces a new agonist, the wind, giving rise to a second comparison, namely to the Baltic Sea and - as indicated by the past tense - to former times and former words and languages. This blending of space, time and language is of course a meaningful indicator of the complexity of the novel's structure - but for now I will not explore its meaning. I prefer to ask one final question concerning the force dynamics presented in the opening lines of the text: Is it the wind that causes the long waves? Would it be true to describe the real force-dynamic behind the sweeping of the long waves as the result of an agonist wind and antagonist waves? 


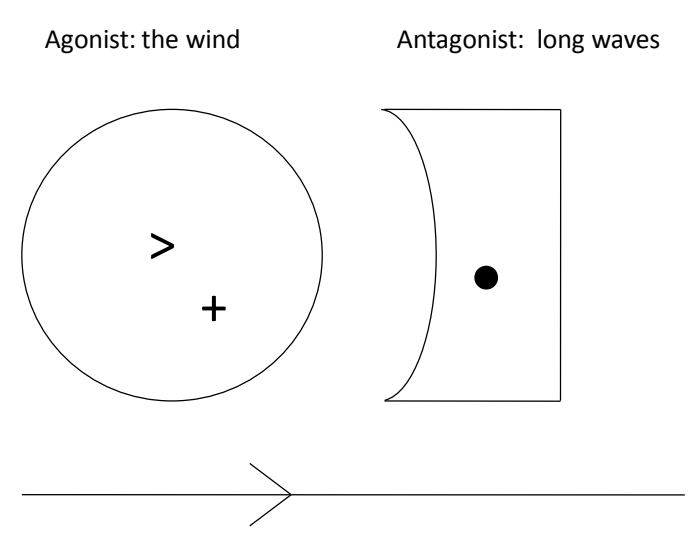

??

Figure 4

Is this true? And if so, how could we subsequently explain that the same wind causes short waves in the Baltic? I am not sure whether the wind causes the waves - nor of which sort. And the text does not give any firm hint that would allow the reader to reach a conclusion. Nobody knows for sure whether waves knock people off their feet or pull them over. Sometimes they knock them off balance, sometimes they don't. And though we know how complex the way in which they build up their force really is (the text even inviting us to imagine it as the creation and destruction of a secret), we know neither how that concrete result will occur nor where the force itself comes from.

Perhaps you are thinking to yourself: a lot of words, just to state movement especially one lacking explanation and refusing predictions and expectations. . But this is actually what Johnson's Anniversaries is about: showing movement, showing what happened, showing the insight of the waves, coming close to what would be a secret without any premature conclusion and without any affinity to prediction. The novel does not try to explain what happened, it does not offer predictions or fulfil expectations. Our first force-dynamic relation is as provisional as the second and together they lack the fundamental question of whether the waves are moved by themselves or by any other force. And there is something else about waves: they follow one after another as if their force were endless. Without an agonist that makes them move and without an end to come, the long waves seem to be more a symbol of time than of history, more a symbol of duration than of change. We could say, therefore, that long waves represent the domain of forces of indecision - maybe even of forces which cannot be understood. Movement without change, movement building up and falling down, knocking people off their feet and pulling them over, this is the conception of force-dynamics we find in Uwe Johnson's Anniversaries. We recognize 
its attention to complexity, a complexity that refuses any brief summary. We might call it inconclusive complexity.

Let us now compare these results with Peter Weiss' The Aesthetics of Resistance. Like Johnson's Jahrestage, Die Ästhetik des Widerstands was conceived in three volumes, published in 1975, 1978 and 1981 respectively, at about the same time as Johnson's work. Over nearly one thousand pages, Weiss presents a kind of fictitious autobiography of a nameless narrator who spends his youth in Nazi Germany, participates in the Spanish Civil War and finally reaches exile in Sweden. The reader follows the narrator on this journey, without actually knowing much about his personal life. Instead, the narrator gives voice to those he meets on his way, to his friends and fellow combatants as well as to the artists and heroes of the artworks he appreciates and studies. Thus, the novel turns out to be a history of resistance - starting on the first page with ancient Pergamum and the rising of the giants against the gods, continuing through the Middle Ages and the 19th century up to the end of World War II. At the same time, the novel is a debate on art pieces which in some way represent or this history of resistance, searching for what one might call an aesthetics of the oppressed and of their fight for freedom: an Aesthetics of Resistance. As in Jahrestage, it is not possible to account for all the details or subjects dealt with by Weiss' monumental work. But we can try to understand the main concept of history that determines the interpretation of historical experience in the world created by the narrator.

Fortunately, I can base my arguments on the fundamental study developed by Ana Margarida Abrantes in her book Meaning and Mind: A Cognitive Approach to Peter Weiss' Prose Work which was recently published. Let us look again at the first lines of the text - we cannot discuss the whole first paragraph because it is about nine pages long:

All around us the bodies rose out of the stone, crowded into groups, intertwined, or shattered into fragments, hinting at their shapes with a torso, a propped-up arm, a burst hip, a scabbed shard, always in warlike gestures, dodging, rebounding, attacking, shielding themselves, stretched high or crooked, some of them snuffed out, but with a freestanding, forward-pressing foot, a twisted back, the contour of a calf harnessed into a single common motion. A gigantic wrestling, emerging from the gray wall, recalling a perfection, sinking back into formlessness. A hand, stretching from the rough ground, ready to clutch, attached to the shoulder across empty surface, a barked face, with yawning cracks, a wide-open mouth, blankly gaping eyes, the face surrounded by the flowing locks of the beard, the tempestuous folds of a garment, everything close to its weathered end and close to its origin. (Weiss 2005: 3$)^{4}$

4 "Rings um uns hoben sich die Leiber aus dem Stein, zusammengedrängt zu Gruppen, ineinander verschlungen oder zu Fragementen zersprengt, mit einem Torso, einem aufgestützten Arm, einer gebrochenen Hüfte, einem verschorften Brocken ihre Gestalt andeutend, immer in den Gebärden des Kampfs, ausweichend, zurückschnellend, angreifend, sich deckend, hochgestreckt oder gekrümmt, hier und da ausgelöscht, doch noch mit einem freistehenden vorgestemmten Fuß, einem gedrehten Rücken, der Kontur 
Right in the first line there is an anonymous force at work upon the subject of the sentence: the bodies are "crowded into groups, intertwined, or shattered into fragments", an anonymous agonist working against the antagonist bodies:

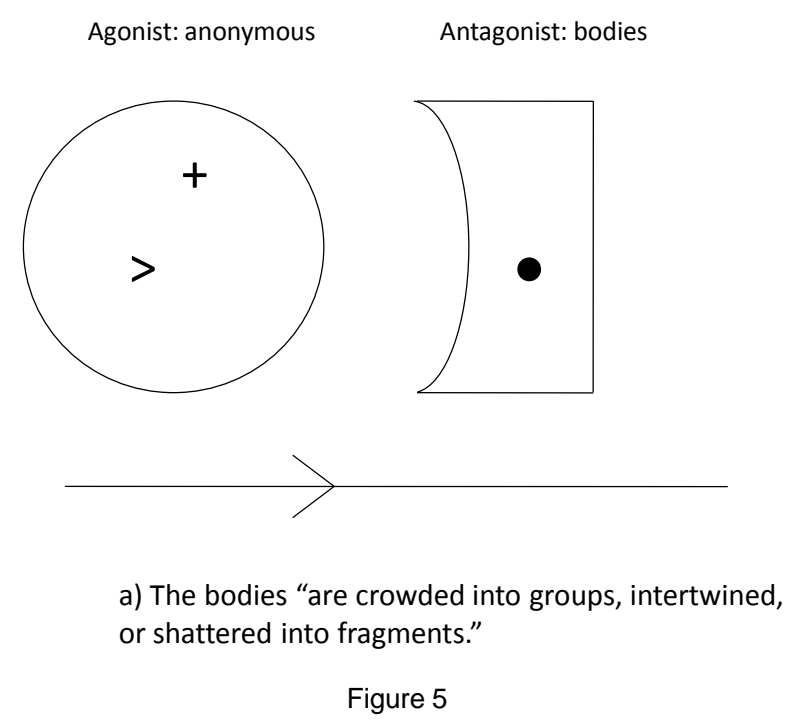

Just as it makes sense that the agonist remains anonymous, so it is also striking that its force leads to two different results: crowding or joining on the one hand and shattering on the other. But there is also another movement, the movement of the bodies themselves which "rose out of the stone" in a kind of resistance against the greater force of their antagonist "stone". Developing Talmy's patterns we might imagine the scene as following:

einer Wade eingespannt in eine einzige gemeinsame Bewegung. Ein riesiges Ringen, auftauchend aus der grauen Wand, sich erinnernd an seine Vollendung, zurücksinkend zur Formlosigkeit. Eine Hand, aus dem rauhen Grund gestreckt, zum Griff bereit, über leere Fläche hin mit der Schulter verbunden, ein zerschundnes Gesicht, mit klaffenden Rissen, weit geöffnetem Mund, leer starrenden Augen, umflossen von den Locken des Barts, der stürmische Faltenwurf eines Gewands, alles nah seinem verwitterten Ende und nah seinem Ursprung." (Weiss 1991: 7) 
Agonist: anonymous Antagonist: bodies

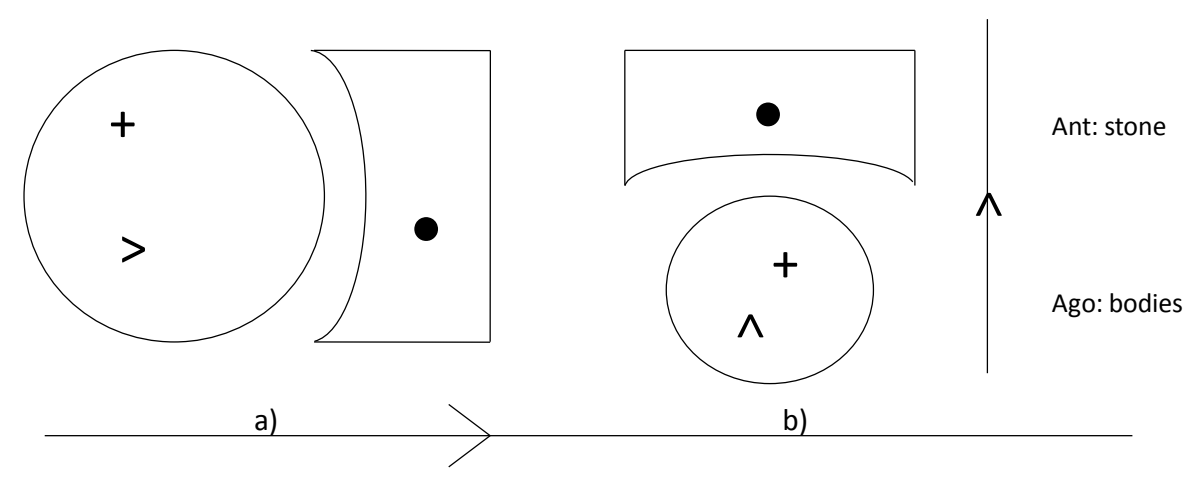

a) The bodies "are crowded into groups, intertwined, or shattered into fragments"

b) The bodies "rose out of the stone"

Figure 6

The relation between these two movements is presented as a conjunction of force in simultaneity: moving and being moved. As a) inverts b) the verbs attributed to the bodies as agonist seem to oscillate between a minor force ("dodging", "crooked", "snuffed out") and a major one ("attacking", "stretched high", "freestanding, forwardpressing"), resisting and rendering in a continuous flow of force dynamics: "always in warlike gestures" and in "a single common motion".

The same seems to be true for the pieces of art the protagonists are observing in this scene: "the gigantic wrestling" is simultaneously "recalling a perfection" and "sinking back into formlessness". The main idea depicted in the first lines is thus, as in Johnson's work, the predominance of an anonymous force causing multiple effects. But other than Johnson's this force is counteracted by the movement of rising out, interrupting the course of the predominant force without nonetheless interrupting its further impact. We can thus follow Ana Margarida Abrantes in the force-dynamic model of resistance that characterizes Weiss' concept of history (Abrantes 2010: 295): 


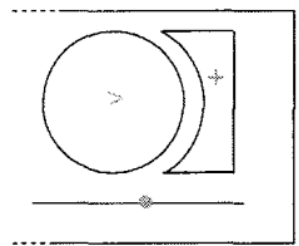

dominance

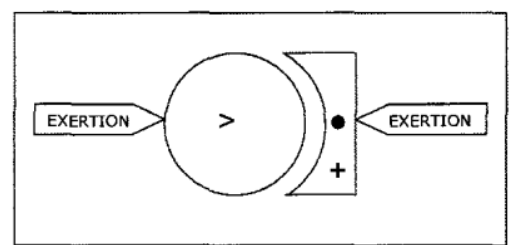

resistance

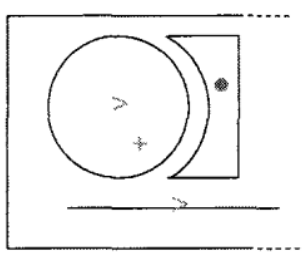

overcoming

Force dynamic model of resistance.

Ana Margarida Abrantes: Meaning and Mind. A Cognitive Approach to Peter Weiss' Prose Work. Frankfurt/M. et al.: Lang 2010 (= passagem 3), p. 295.

Figure 7

As Ana Margarida Abrantes shows, there will be multiple inputs of resistance throughout the novel. But the dynamic model is always the same, as can be seen by the narrative dynamic model for the concept of resistance (Abrantes 2010: 297).

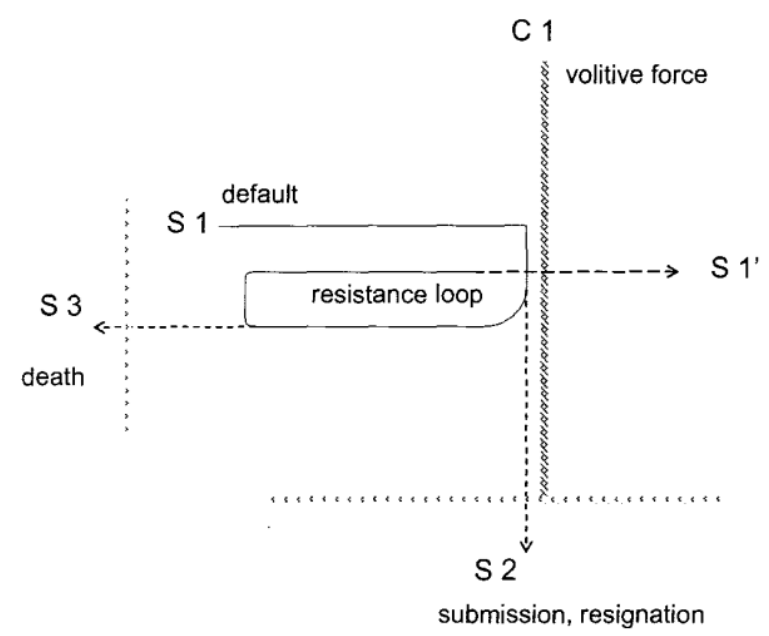

A narrative dynamic model for the concept of resistance.

Ana Margarida Abrantes: Meaning and Mind. A Cognitive Approach to Peter Weiss' Prose Work. Frankfurt/M. et al.: Lang 2010 (= passagem 3), p. 297.

Figure 8

\section{Abrantes writes:}

A person or group finds itself in a departure situation (S1), which they expect to continue to S1' by the mere passing of time [a kind of vanishing point in the future; $\mathrm{PH}$ ]. At some point, they face a barrier $\mathrm{C} 1$ which prevents them to reach $\mathrm{S} 1$ '. This obstacle can be a 
volitional agent, who deliberates to hinder the intents of the agents in S1. The result is that the agent in S1, previously in a neutral condition, is now headed for a crisis (S2). If this is permanent and the initial balance cannot be re-established, the crisis can lead to a qualitative change in the agent (represented by the crossing of the lower horizontal line), so that it permanently becomes S2 [...]. In terms of the dynamics of resistance, this S2 corresponds to the permanent condition of oppression. $\mathrm{C} 1$ corresponds to the intentional behavior of another agent (the oppressors), who have the power to influence the initial condition of the persons in S1. S1 resigns and complies to its new condition, despite it being indeed an aggravation or unbalanced condition. An alternative to this development is an even more dramatic condition inflicted on the person in S1 by the impact suffered as it meets the barrier. The subject can recede to a condition from which there is no possible return: he cannot accept or resign to the dysphoric condition, he also is not strong enough to fight and overcome the barrier, and instead bounces back by the strength of the barrier to a condition that is prior to $\mathrm{S} 1$ : non-existence. [...] The only possibility for the agent in S1 to restore its original default condition is to insist on this condition against the volitional force of the agent of $\mathrm{C} 1$. This is represented in the schema as a loop, by which we intend to configure the impact of the harmful barrier and the dynamic reaction to it by the exertion of force. Only the intended goal of S1 is known, namely restoring the initial condition (hence the dotted line also towards SI'). (Abrantes 2010: 297-298)

The text establishes a vanishing point in the future which will not take place - hence its condition of utopia. And Abrantes continues to explain how this concept can be understood even as a continuous process. She writes:

Resistance implies a minimal duration: in this temporal stretch, the loop can be repeated in a rhythmic exertion of force, representing the recurrent actions carried out by the subject in $\mathrm{S} 1$ to oppose the barrier. In the following diagram, these actions are represented by $\{X\}$, which denotes an insistence or repetition of the actions carried out by the persons in $\mathrm{S} 1$ to overcome the volitional barrier imposed on them by the entity in $\mathrm{C} 1$. (Abrantes 2010: 298) 


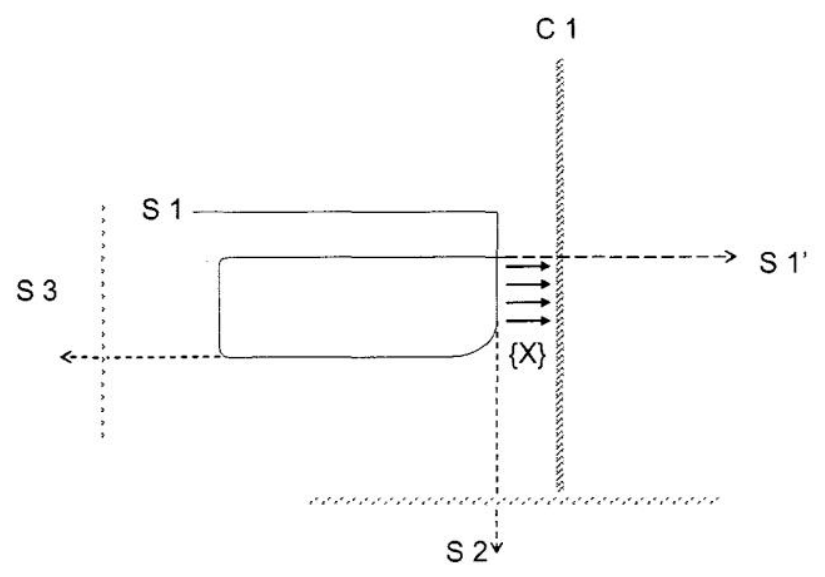

A narrative dynamic model for the concept of resistance (multiple input of resistance against opponent barrier).

\section{Ana Margarida Abrantes: Meaning and Mind. A Cognitive Approach to Peter Weiss' Prose Work. Frankfurt/M. et al.: Lang 2010 (= passagem 3), p. 298. \\ Figure 9}

In this sense, the narrative dynamic model for the concept of resistance turns out to be a "timeless" schema that even determines the structure of the narrative schema itself, as shown in the following diagram:

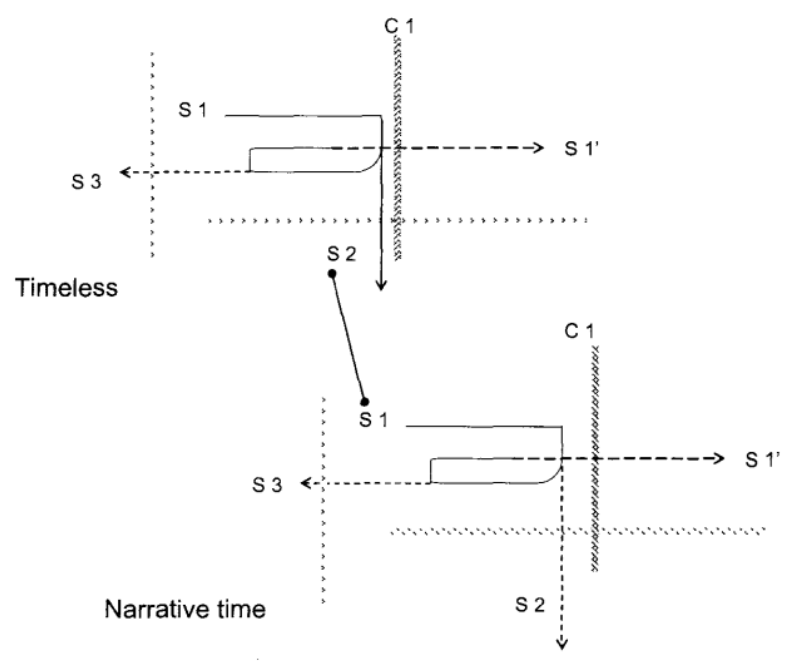

A narrative dynamic model for the concept of resistance: continuity between the
timeless schema of resistance and the narrative schema of resistance in "Die Ästhetik des Widerstands".

Ana Margarida Abrantes: Meaning and Mind. A Cognitive Approach to Peter Weiss' Prose Work. Frankfurt/M. et al.: Lang 2010 (= passagem 3), p. 299.

Figure 10

The clue is that the continuous line of S2 in the upper part of the diagram portrays the permanent and repeated defeat before the stronger opponent barrier $\mathrm{C} 1$, the result of the force-dynamics, which is well known, historical and factual. The narrative develops its own structure as a repetition of the concept of resistance under the 
condition of permanent oppression and failure. It opens up a new loop whose result can be predicted as belonging to the domain of submission and resignation.

One may consider this quite unsatisfactory or even contradictory. Perhaps at this point contemporary readers no longer find the answers or the pleasure they were looking for in Weiss' Aesthetics of Resistance. The end of the East-West-Conflict not only abolished the concrete historical setting in which Weiss' work is imbedded; it even made an experience possible for which his concept of history and force dynamics could not account: a revolution that solved a problem and provoked a thousand new ones, problems which do not obey the concept of resistance. It seems to me that the clash of civilizations (if it exists) cannot be understood using the concept of resistance, and nor can economic crises, consumer society, migration or however you might wish to characterize liquid modernity (Bauman 2000) and contemporary hybrid cultures (Canclini 2005). Conviviality seeks out a different kind of force dynamics (Gilroy 2004).

Readers of Weiss' book might feel that since he wrote there must have been a turning point, one which provoked a worldview that does not conform to the concept of resistance as developed in his work. And the same readers may find Johnson's Anniversaries too inconclusive with its long waves of exhausting complexity. Of course, both works document a situation and a state of mind that historically marked an era which they were able to portray and to represent in an outstanding and singular manner. Both works continue to be amongst the best literary representations of postwar state of affairs - and as such are witness to an admirable aesthetic mastery and are of inestimable value to cultural memory.

But the simplicity of one model and the undecided complexity of the other might not actually be concepts of force-dynamics in contemporary culture, where problems and challenges are multiple and concrete, and where solutions are supposed to be possible and achievable. Like historical narratives of a divided world, timeless concepts, too, seem to have burnt out: neither long waves nor vanishing points, just hard work to do.

\section{Bibliography}

Primary literature

Johnson, Uwe. 1975. Anniversaries: From the Life of Gesine Cresspahl. New York/London: A Helen and Kurt Wolff Book. . 1988 [1970]. Jahrestage. Aus dem Leben von Gesine Cresspahl. Frankfurt (Main): Suhrkamp.

Weiss, Peter. 1991. Werke in sechs Bänden. Frankfurt (Main): Suhrkamp. 2005. The Aesthetics of Resistance. Durham/London: Duke University Press. 
Secondary literature

Abrantes, Ana Margarida. 2010. Meaning and Mind: A Cognitive Approach to Peter Weiss' Prose Work. Frankfurt (Main): Lang.

Bauman, Zygmunt. 2000. Liquid Modernity. Cambridge: Polity.

Canclini, Néstor García. 2005. Hybrid Cultures: Strategies for Entering and Leaving Modernity. Minneapolis/London: University of Minnesota Press.

Gilroy, Paul. 2004. After Empire: Melancholia or Convivial Culture. London: Routledge.

Hanenberg, Peter. 1993. Peter Weiss. Vom Nutzen und Nachteil der Historie für das Schreiben. Berlin: Erich Schmidt.

Hanenberg, Peter. 2011a. "Cognitive Culture Studies - Where science meets the humanities" In: Ana Margarida Abrantes, Peter Hanenberg (eds.) Cognition and Culture. An Interdisciplinary Dialogue. Frankfurt (Main): Lang. 37-46.

Hanenberg, Peter. 2011b. "My Favorite Things'. The proximal term of tacit knowledge" In: Mario Franco, Bernd Sieberg (eds.) Proximidade e Distância. Estudos sobre a Língua e a Cultura. Lisboa: UCE. 169-179.

Hofmann, Michael. 1995a. “"̈sthetik des Widerstands' und 'Jahrestage': Ansatzpunkte für einen Vergleich.” In: Uwe Johnson. Zwischen Vormoderne und Postmoderne. Berlin: de Gruyter. 189-199.

. 1995b. "Das Gedächtnis des NS-Faschismus in Peter Weiss" 'Ästhetik des Widerstands' und Uwe Johnsons 'Jahrestagen'." In: Peter-Weiss-Jahrbuch 4: 5477.

Honold, Alexander. 2002. "Working on German Memory. Peter Weiss and Uwe Johnson." In: Adrian Del Caro, Janet Ward (eds.). German Studies in the PostHolocaust Age. Colorado: University Press. 206-213.

Knoche, Susanne. 2002. "Generationsübergreifende Erinnerung an den Holocaust. 'Jahrestage' von Uwe Johnson und 'Die Ästhetik des Widerstands' von Peter Weiss.” In: Johnson-Jahrbuch 9: 297-316.

Pflugmacher, Torsten. 2007. Die literarische Beschreibung: Studien zum Werk von Uwe Johnson und Peter Weiss. Paderborn: Fink.

Rector, Martin. 2005. "Wahrnehmung und Erinnerung in Peter Weiss' 'Ästhetik des Widerstands' und Uwe Johnsons 'Jahrestagen'.” In: Johnson-Jahrbuch 12: 91-100.

Schnell, Ralf. 1986. Die Literatur der Bundesrepublik. Autoren, Geschichte, Literaturbetrieb. Stuttgart: Metzler.

Talmy, Leonard. 2003. Toward a Cognitive Semantics. Cambridge (Mass.): MIT. 